\title{
FUNCTIONING OF FINANCIAL AND CAPITAL MARKETS IN MODERN CONDITIONS
}

\author{
Ljiljana Stosic Mihajlovic, PhD \\ High School of Applied Professional Studies, Vranje, Republic of Serbia \\ E-mail: mihajlovicp@ptt.rs
}

Original Scientific Paper

doi:10.5937/jouproman4-12134

\begin{abstract}
Financial markets are the lifeblood of the global economy where changes in one part of the world quickly and violently, like waves, spread and affect every country, company and individual. This is most clearly manifested in the great world economic crisis that began precisely on the US financial market, that is where the market is most developed, and extended to all other countries. Financial markets in the modern world are associated with the other segments of the world economy. To understand the phenomenon and fluctuations based on this exhibit, today more than ever necessary to monitor the total change, not only in in economy but also in all other segments of society. The complexity of the mechanisms of financial markets, the large number of participants, the importance of regulation and supervision, but high profits and high risks, so that the understanding of financial markets today are more complex than ever before.
\end{abstract}

Key words: capital market, financial markets, the financial sector

\section{Introduction}

The global economic crisis in a relatively short period of time has led, however, a dramatic fall in the stock market, bringing down share prices and companies which are economic parameters resisted the crisis, but could not resist the psychology of mass spreading panic and fear of investors. It is also shown, and all the multidisciplinary nature of financial markets whose understanding is all the more important to know the theory of the behavior of market participants. Institutional investors are the most important creators and participants in financial markets, and will therefore study their role to be given special attention.

Nobody ever says a Spanish proverb, he did not know as much as his life was necessary, or - must learn. (Božić, 1994). Capital market represents a space on which face supply and demand for capital. Capital represent all securities with a maturity of over one year. There are primary and secondary capital market. The capital market incorporates in itself the following three markets: credit and investment market, the mortgage market and the securities long-term character. Sources of capital in the context of a national economy are financial savings, transformation into capital, ie, loan capital and equity. On the capital market practically the buyer and seller agree on a capital case and the terms of the sale, but the most important requirement of any purchase of capital is its price. As participants in the capital market are most often capital investors, entrepreneurs, capital, intermediaries in the form of banks and other financial organizations specialized financial institutions such as stock market and the state. From the aspect of market relations, the participants in the capital market can be classified as direct participants and indirect participants.

Wholesalers in the capital market are the smallest, but the most important is for the participants in the capital market. All agents are classified into three large groups and to the banks or other financial institutions, investment funds and stock exchanges as well as specialized functions. 
The role of banks in the capital market can be traced through their activity in the primary and secondary capital market.

In modern market economies, there is a strong development of investment funds whose aim is to improve the process of buying securities by investors. There are various forms of investment funds - open, closed and term investment fund. General systematization investment fund knows that investment funds assets are invested in shares, investment funds, which assets are invested in bonds and investment funds that invested in money market instruments. Also, insurance companies are important institutional investors in the capital market. They can be organized as joint stock companies or as joint venture company, and according to the subject of insurance can be divided into those that provide life and to those that provide property. A special category is represented by pension funds forming corporations, unions or governments for the payment of pensions of retired workers and there are two basic types of pension funds - pension funds, private pension funds and the type of public type. Thus, capital market represents institutionally organized space with all the necessary elements for its functioning in a given time, according to defined rules and practices of conduct for all participants. In this area and in the context of its environment while respecting the rules of conduct, organized to meet supply and demand of capital.

The capital market basically is a specialized market in which money, that is, capital seeks and offers long-term and on which are traded already issued long-term securities. Primary capital market plays a vital role in the creation of capital, which means that it creates in the capital and initial sales in the capital market. Secondary Market capital in the primary market acceptance issued shares and bonds and determines the conditions to be traded. It is noteworthy that the capital market is no appearance of financial resources but performs the supply of long-term securities.

The OTC market's way of functioning of the market system agreed. Unlike money market, capital market institutional character, in the market economy. Transactions in such a market and in the framework of these institutions place called capital transactions, while securities traded in the capital market are called effects. Accordingly, the market effects of only one segment of the capital market, which is actually a complex market category. The subject of sale and purchase transactions in the capital market solely capital, ie, funding long-term character. This practically means that the concept of equity in terms of capital markets equated with the concept of savings and term placements, and saving for a period of not less than one year. It is also important to point out that three specialized markets, classified according to financial instruments for buying and selling, make the capital market.

The financial market is a transmission mechanism for lending funds to business entities that have surplus funds to those who need these funds are missing for certain business activities.

The transfer of the first group to another takes place through the credit deposit mechanism in the banking sector and through issuing securities issued by issuers who have the resources needed. (Stošić Mihajlović, 2014)

The narrow definition of financial markets linked to the term of the securities market. The basic functions of the securities market are:

1. Providing opportunities to corporations and governments to raise capital

2. Good to efficient allocation of capital to companies and projects

3. Enabling households to increase savings by investing through this market 
4. Enable investors insight into potential earning opportunities in the market, serving as a guide for decision making management corporation

\section{To generate employment and income.}

The development of financial markets spread and range of financial instruments. In addition to funding by issuing shares and has developed variety of financial instruments based on debt securities, and more recently have experienced expansion and financial derivatives. The most famous and equity instruments are shares and debt instruments known as bonds. As the most famous shortterm debt securities may be taken treasury bills issued by the US government, which have maturities ranging from 90 to 360 days and can be considered the equivalent of cash because they are liquid at any time and are only in the form of entries in the books (book entry form). In addition, money market instruments are: commercial paper, banker's acceptances and other instruments.

The most common is the division of the financial markets on the capital market and the money market. This division is related to the maturity of the securities, including capital markets are the financial debt instruments that have a maturity of over one year and equity securities, the actions of course and have no maturity, while money market instruments belonging to the cash and debt securities with a maturity of up to years. The most important one part of the capital market makes the stock market or the market in which you make stocks (equity securities related to the share capital expressed in shares) .This is typical for Anglo-Saxons market, i.e. the United States and Britain.

\section{Informational Basis, Research Methodology and Research Questions}

In the following, I will have revenge problems:

- Capital market has always had an role in achieving the well-being. Capital market follows the trends and tendencies in the national financial market and world economy;

- State regulation and positive legislation provides adequate support financial sector. It is a notorious fact that they have a negative effect on the financial market pre-defined strict rules he movement of the leading financial institutions in Serbia.

The dominant research method that was used during the preparation of this scientific paper is a scientific method based on the available data and the information made available through the scientific community. Thus, the method of research "at the table" is dominant when it comes to the collection of data but also their checks on reviewing material from multiple sources about the problems of functioning of modern financial markets. So, applied research methods are the methods of synthesis and analysis. Analysis as a research method is used when talking about in the capital market, financial markets, with special emphasis on the situation of the capital market in the Republic of Serbia.

\section{Research Results and Discussion}

The European Union countries are represented more financing through the banking sector and stock markets reserved only for the biggest and best companies. Increasingly, developing and financing through debt securities in order to reduce dependence and reduce the risks of the banking business. (Jeremić, 2012). 
Table 1. Dominant forms of financing

\begin{tabular}{|c|c|c|c|}
\hline Business Size & small businesses & medium-sized & Big businesses \\
\hline $\begin{array}{c}\text { The dominant form of } \\
\text { financing }\end{array}$ & Bank loans & Direct placement & $\begin{array}{c}\text { Public offer - stock } \\
\text { market }\end{array}$ \\
\hline Maturity & of short-term & often rarely & often rarely \\
\hline Security & always & Very often & Rarely \\
\hline Monitoring by the investor & intense & medium & Underwriters \\
\hline
\end{tabular}

When it comes to financing the socalled "small business" the most appropriate forms everywhere in the world of bank loans. Maturities are mostly shortterm, but depending on the purpose and type of loan can be in the medium term, usually 5 years. If it is a medium size company which has Significant assets and wants to fund say the procurement of machinery and equipment, loans can be up to ten years with a "grace" period, or more popularly grace period of one to three years. It is believed that the risks in extending these loans are high, as shown by the statistics, and for several reasons. First, a large number of small businesses in the world start every year, but a high percentage off. There are as it is for example the case of large, well-known companies, the information on doing business in the longer time series, i.e. there is no history, so it is difficult to analyze the company's credit worthiness. [2] This is particularly important for lending operations in the so-called establishment. Therefore, contracts are strict, and always require a firm assurance from the entrepreneur. But in developed countries, the state, knowing of these problems, and bearing in mind the importance of SME development, establishing the guarantee funds and specialized institutions to reduce risk and to assist in the development of these enterprises.

When, however, comes to financing medium and large businesses, in addition to bank loans is imminent and financing through the capital market. The capital market brings together companies that lack long-term funds for the development of business activity, with investors who have funds to invest, or surplus funds, which are saved and who would like to sell for profit. For the company's money is important to be able to develop and exercise the projects that will strengthen their market position and overall references, and thus higher profits. To achieve this, companies need to have the capital to ensure: fixed assets, ie buildings, machinery and other equipment, to pay workers and to fund research and development. To secure the required additional capital companies in less developed economies where not functioning satisfactorily capital markets, mainly those needs are financed by bank loans. In a country where over 92 percent of the financial sector consists of banks, it is logical that more than 70 percent of businessmen who used to borrow bank loans, followed by 15 percent of those who borrow funds from family and friends. 
In contrast to these indicators in Europe and the region's more developed capital markets, and entrepreneurs have a wider choice of external funding sources, including non-deposit taking microfinance institutions. They are particularly suitable for start-up and micro businesses, because, unlike banks, which is mainly rely on historical indicators on the operations and performance of clients, microfinance is based on closer ties with the client, a deeper analysis of business ideas and their feasibility.

In developed countries, companies finance these needs not only bank loans, but also through fundraising issuing securities or capital markets. Financing is being played by the private or state-owned company transformed into a company open to the public and conducted emissions and the placement of its securities which can be traded freely. This process is known as "going public" or going out in public. Thus, the company actually sells part ownership of your business every single investor or buyer of shares and so then satisfy the financial needs of raising capital. In contrast to the public, open company, private, closed companies raise capital only from its members not getting out to the public, and therefore not subject to all the obligations which raise capital on the market means.

The privatization process of which has now implemented represents some form going public or transformation of social and state enterprises in open joint stock companies - corporations. In developed economies the main reason why a company becomes a public limited company is that its owners, state or private owners, in this transformation, see the benefits for the company, especially in terms of financing its development and in terms of management. When a company decides to take on this kind of financing it, it is in developed economies mainly works through the investment banks or investment dealers or underwriter - guarantor emissions. Its task is to make an initial offer of shares on the market, or the first issue of shares intended for purchase by the public. It was a single transaction between the company and the shareholders who buy its shares. The role of investment banks, dealers or guarantor emissions, is to advise the company on the number of shares that will be broadcast and their prices.

With regard to the recapitalization, it is very important that the program is successful, or that the shares are sold, so the investment bank buys the whole show taking time and risk, or only technically conduct the entire operation by working in good faith. This market, where the company first issues shares, called the primary market. (Stanojević, 2015). When a company becomes public when issues shares, these shares are traded on the stock exchange. Before that, however, it must meet the standards set by the stock exchange that must be listed on the stock exchange. The market in which the company has issued shares are bought and sold is called the secondary market. The investor may be called. Institutional, such as companies that do business with the pension and mutual funds, banks and insurance companies, as well as individual investors will. Investing in stocks involves understanding the risk that when it came on, and the relationship of risk and height of potential profits. Therefore, it is in the developed economies developed and profession of investment advisors who help clients to invest in accordance with the position they prefer. Investments must be adapted to the amount of wages or income of the client and the amount of savings you have. Some customers prefer high-risk investments in order to achieve high profits, while others prefer to invest in safer securities, but with lower earnings potential.

Financial or capital markets are like other markets, with the only difference what does not work on goods, services or labor, but on the equity in the narrow financial sense. 
At the same time, these are the four main markets, which exist in almost all market economies. Funding capital markets, securities, in paper form and are traded e. Since the subject of trade today largely dematerialized, the term "securities of the values together "is not appropriate, but I'll keep him here because of the established habits in the use of the term in scientific, business circles and the general public. The majority today's trading on capital markets are done through the exchange of dematerialized property rights. Of course, the main purpose of this exchange or trading profit.

Markets are needed to determine the main features of the capital - the price. The price provides an incentive for individuals in the circumstances direct capital the most productive use due to personal preferences, primarily attitude towards risk. (Friedman, 1998) Serbia is an emerging market, and in this sense does not differ significantly from the other emerging markets. More specifically, Serbia as an emerging market beginner. Many describe this stage as a small-scale commerce, small depth, with a little liquid securities and unstable. Later we will see that the trade in Serbia and expensive, much more expensive than others, especially developed markets. The presence of the above mentioned characteristics does not mean that emerging markets are not attractive to business. But before we deal with this problem, we'll discuss some characteristics of emerging markets. In contrast to developed markets, where prices are stable and the risks to the generally lower market in development abundant to price instability and high risks. Tomas Dvorak and Richard Podpiera, estimated that the volatility of world stock markets between 2001 and mid-2004 was nine times lower than the average market shares of the new member states of the European Union. Mentioned to investors, who operate in a more or less risky markets to diversify their investments, ie. portfolio.

\subsection{Serbian Capital Market}

The capital market, is a place where you meet supply and demand for capital. Under the capital are considered different types of financial instruments, - securities (HOV) whose maturity longer than one year. The most widely viewed on the capital markets appear to be three main participants - issuers (issuers of securities), investors and states that can be borrower and lender of capital. In the role of borrower usually appear enterprises in the capital markets to issue securities to raise the necessary funds. In his role as lenders usually are entities with surplus funds and can be individual investors, households, other economic operators as well as the country.

On the capital market, there is also a large number of participants that facilitate the confrontation of supply and demand for capital, or connect borrowers and lenders. The most commonly occur as participants:

- Commercial banks

- Investment funds

- The broker - dealer companies

- Voluntary pension funds

- Insurance companies

- Investment banks

Money market, as part of the capital market, dominated by a very restrictive Central Bank (NBS, the National Bank of Serbia). Rates reserves NBS provides, are very high, ranging up to $60 \%$ in mid 2006. Required reserves of banks in the world are moving between $3 \%$ and $10 \%$. High reserve requirements are a major factor of high interest rates in Serbia, since the commercial banks are forced to earn the rest of $40 \%$ for the whole the sum of the deposit. As a result, interest rates on deposits low enormous, and the borrowings enormously high. 
Both companies and individuals who borrow pay a very high price NBS wrong policies. The central bank reserve funds held in accounts at banks Europe and this gets miserable interest. That the funds remained in the hands of commercial one bank to earn significantly more, because they are willing to accept greater risk. It is obvious that in this way the collapse of NBS assets of commercial banks that forced holding in reserve and prevents owners of banks and deposits to obtain higher earnings which results in longer stay in poverty.

Another major problem that NBS does not manage successfully to solve the issue of the exchange rate. Dinar are not traded on European markets, while the dinar exchange rate forming NBS can considered administrative. The dinar exchange rate is not adjusted, even with the rate of inflation, which are double digits in recent years. As a result, the world's currencies are losing purchasing value in Serbia. An additional problem is the imbalance in the movement of foreign money. Foreign money in the ground comes easy, but it hardly comes out of the earth, because the monetary authorities and other not yet grown primitive belief that the liberalization of foreign exchange flows led to an outflow of foreign exchange and "Draining the foreign exchange market". In a small economy, where foreign money comes easily and goes difficult, the central bank can be very difficult to maintain a normal course of the domestic currency. Because of addition, there is constant pressure to increase the value of the dinar, whose value can not harmonize with inflation. So with a strong dinar prices rise (due to increased amounts of foreign money, which hardly comes out of the ground). Due to unrealistically high prices, US is a key factor the huge deficit in the trade and current account, a factor in the poor judgment Corporate and household borrowing (a sudden drop in the value of the dinar would significantly impede repayment borrowings). Above all, the NBS held closed banking market in Serbia, which is why the services of banks expensive and of poor quality, while the extra-bank rents are very high. These Problems can not be solved without a complete change in the policy of the NBS, which now avoids any reform, as it would fall in the value of the dinar and earning a rise in inflation was disclosed the price of previous wrong policies.

\subsection{Serbian equity market regulators}

The main organ that is responsible for the planning and implementation of trade in accordance with the laws of the Republic of Slovenia eating Securities Commission of the Republic of Serbia. The Commission is a legal entity, independent and autonomous organization of the Republic of Slovenia, which is responsible for the conduct of the National Assembly of RS. This body was founded on February 16 1990 and consists of five members, including the President of the Commission, which, at the proposal of the competent working body for finance RS National Assembly, elected and dismissed by the National Assembly of RS. The Commission is responsible for the lawful operation of the securities market, with the aim of protecting investors and ensuring the fairness, efficiency and transparency of the market. Responsibilities and powers of the Commission are regulated by:

- Capital Market Act ("Off. Gazette of RS", no. 31/2011);

- Law on Takeover ("Off. Gazette of RS", no. 46/2006);

- Law on Investment Funds ("Off. Gazette of RS", no. 46/2006)

Central Depository and Clearing House (Central Securities Depository) is an institution whose business includes the registration of different securities, which include bonds, stocks, treasury bills, treasury bills, etc. 
Some of the functions of the Central Registry are: the opening of securities accounts and cash accounts for individuals and legal entities, transfer of securities from the account prior to the account of the new owner, the registration rights of third parties securities (eg. A lien), perform the clearing and settlement of securities and funds, etc.. Under the clearing and balancing acts are considered after the conclusion of the trading securities, respectively, represent a mutual alignment of receivables and payables, as well as the transfer of the sold securities (from the old to the new owner) and the transfer of financial resources (from buyer to seller's account). Central Registry was established on 19 November 2001 as a closed joint stock company with rights, obligations and responsibilities defined by the Law on Companies ("Off. Gazette of RS" no. 125/2004) and the Law on Capital Market ("Official Gazette of RS" no. no. 31/2011).

\subsection{Some problems of the capital market in Serbia}

There is no clear evidence which shows that investments in the portfolio caused long-term growth of an economy. Some records show a negative relationship. In spite of mentioned, investors can benefit greatly, as their profits related expectations for growth, rather than BDP. Hence, it is desirable to have more rather than less to investors Capital markets. One of the major problems Serbian capital market is that there are a small number of species securities trading. In addition to shares of corporations, traded bonds' old savings "19 and bonds the central bank. Continuous, trading in shares of 20 to 30 companies in 2005 and 800 companies from time to time. In 2006, it reduced the number of shares on the continuous trading at 15-20, and increased the number of shares of companies that are generally traded on about 1000 . Of these 1000 really only traded shares of less than 200 companies.
Main subject to trade the shares of privatized companies. Shares of some companies on the stock exchange are not subject to trade and after more than a year. The first shareholders were mainly individuals and states (Including institutions), the first buyers are investors and funds. A small number of private individuals participating in the purchase of shares - according to estimates in brokerage circles this is just 5000-6000 individuals. Greater care for the securities market are limited Number of securities - shares of companies, bonds of "old savings" 20 and short-term government bonds. No securities related to the state and debts of companies (ie. no bond, with the exception of "old savings" and most recently Commercial paper NBS), no debt (corporate bonds) or derivatives, such as as futures, options or swaps.

Understand complex phenomena in financial markets, as well as their interdependence is a very difficult task. Companies are faced with making decisions about how their financing in the market. Market conditions play a significant role in deciding whether the company will issue equity or debt instrument. If the stock market is growing and there are estimates of its further rise, the shares of the company are well on the stock market, it is logical to raise additional capital by issuing shares. High stock prices means that the additional capital raise with broadcasting less action, and that means that the so-called equity dilution of existing shareholders will be less. If the stock market is constantly declining, the issuance of bonds may be the only rational solution. Interest rates in the market are also important in deciding which instrument output. High interest rates do not favor the issuance of the bonds due to the high costs which the company would have to pay. 
Bonds are better suited for financing specific projects that can be predicted and projected costs, but to finance the general needs of the company, where it is not possible to make accurate projections. (Prokopijevic, 2006). By buying the shares the investor becomes the owner of the company and share the fate of its successful or unsuccessful operations, but by issuing shares "crushed" percentage of the ownership of existing shareholders own. If it is a good company existing shareholders will wish that they receive pre-emptive rights of such shares, to retain the stake in the company.

\section{Conclusion}

In this paper, the main topic of our research was very important subject is relevant to contemporary business conditions, to the financial and capital markets. The paper discusses the importance and mutual conditionality of the financial markets and its implications on the capital market. The significance of the relationship between these two categories of modern markets, which, given its importance and special regulated legal framework.

The fact is that the modern development of the economic development of all countries quite realize reflected in the development and functioning of the legality of the financial market. Business and economic trends in all countries of the world, including in the economy of Serbia are determined by the level of development of financial markets. In doing so, it is very important legislation that also follows this rule.

\section{LITERATURA}

1. Božić, N. (1994). Tržište kapitala, Dugoročne hartije od vrednosti. Prometej, Zemun

2. Biznis top 2014/15. Dragana Stanojević, USAID Projekta za bolje uslove poslovanja
3. Barjaktarović, S., Benković, S.: (2012). "Model of regulation of financial institutions-case of Serbia", Metalurgia international, 2012.

4. Dugalić, V. (2001). The price of shares, Poles Culture, Belgrade.

5. Finansijska tržišta, finansijske institucije i tranzicija. Tematski broj, Ekonomski anali, June 2002 (XLVII), s. 1-216.

6. Friedman, M. (1998) Kapitalizam i sloboda, N. Sad: Global book.

7. Global emerging markets. Outlook, Credit Suisse \& First Boston, September 21, 2005, na sajtu: http://research-and-analysis.csfb.com/

8. Jeremić, Z. (2012). Financial markets and financial intermediaries, Lux, Belgrade.

9. Prokopijevic, M. (2006). Tržište kapitala u Srbiji. Objavljeno decembra 2006 u zborniku Instituta za evropske studije.

10. Radonjić, O. (2005). Tržišta novca i kapitala: značaj, učesnici i instrumenti, http://www.ubsasb.com/Portals/0/Casopis/2005/7_8/UBSBankarstvo-7-8-2005

11. Stosic Mihajlovic, Lj. (2014). Market, costs and prices, VŠPSS, Vranje.

12. Šoškić, D. (2000). Hartije od vrednosti: Upravljanje portfolio i investicioni fondovi”, Ekonomski fakultet, Beograd

13. Official Gazette of RS" no. 125/2004, Law on Companies)

14. Official Gazette of RS" no. no. 31/2011, Law on Capital Market)

15. Zakon o tržištu kapitala (sl. glasnik RS, br. 31/2011 i 112/2015)

16. www.paragraf.rs/propisi/zakon_o_trzistu_kapitala.ht $\underline{\mathrm{ml}}$

17. http://www.psinvest.rs/sr/trziste-kapitala-srbije, Retrieved on 01.09.216.

18. http://www.trziste-kapitala.com/trziste-kapitala, Retrieved on 05.09.216.

19. finanace.mapsofworl.com, Retrieved on 01.09.216.

20. www.investopedia.com, Retrieved on 11.09.216.

21. www.ukessays.com, Retrieved on 08.09.216. 